\title{
A 26-Year-Old Woman with Bronchial Asthma and COVID -19 Treated by Stand Alone Siddha Medicine: A Case Report
}

\author{
A. Aishwarya ${ }^{1 *}$, B. K. Priya ${ }^{1}$, B. Akila ${ }^{2}$, R. Manickavasagam ${ }^{3}$ \\ 1*Research Associate (Siddha), Siddha Clinical Research Unit, Safdarjung Hospital, New Delhi-110023, India. \\ ${ }^{1}$ Siddha Consultant, Siddha Clinical Research Unit, Safdarjung Hospital, New Delhi-110023, India. \\ ${ }^{2}$ Research Officer (Siddha), Siddha Clinical Research Unit, Safdarjung Hospital, New Delhi-110023, India. \\ ${ }^{3}$ Research Officer (Siddha) In-charge, Siddha Clinical Research Unit, Safdarjung Hospital, New Delhi-110023, \\ India. \\ Corresponding Author: A. Aishwarya
}

\begin{abstract}
Background: Corona virus disease 2019 (COVID-19) is a public health emergency of international concern. The global population lacks immunity to COVID-19 and is generally susceptible. Underlying conditions, especially chronic respiratory diseases, may affect progression, treatment and prognosis of COVID-19. The majority of people who exposed to COVID-19 suffer only mild respiratory symptoms like cough, cold, difficulty in breathing, etc and these symptoms were correlated with Kaba Suram in the Siddha literature.

Case Summary: Siddha Clinical Research Unit, New Delhi (CCRS), Ministry of AYUSH, Govt. of India had reported a patient with confirmed COVID-19 by RT-PCR with bronchial asthma as a comorbid condition. Recovery time from disease onset to negative test for COVID-19 was 19 days.

Conclusion: Since the patient residing in Dwaraka, New Delhi has bronchial asthma as a co-morbid condition, both air pollution and the winter season are likely to increase the severity of the disease. But it was observed that the patient's condition did not deteriorate, so it could be presumed that the management of COVID-19 with the given Siddha internal medicines and external therapies as a standalone treatment ceased the progress of the disease to a severe stage.
\end{abstract}

Keywords: Bronchial Asthma, Corona virus, COVID-19, Kaba Suram, Siddha Medicine

\section{INTRODUCTION}

Corona Virus Infectious Disease 2019 (COVID-19), caused by the severe acute respiratory syndrome corona virus 2 (SARS-CoV-2) has developed into a pandemic. In this context, a plenty of research works in traditional medicines are conducted around the world in the search for potential treatments for COVID-19 [1]. Siddha system of medicine is one among the Indian traditional medicines have wide potential for usage in such conditions owing to their longstanding use in the community, ancient references and clinical efficacy. The majority of people who contract Covid-19 suffer only with mild respiratory symptoms like cough, cold, difficulty in breathing, etc. This case report briefly postulates the efficacy of Siddha medicines in COVID-19.

\section{METHODS}

\subsection{CASE PRESENTATION:}

\subsubsection{Patient Information:}

A 26 years old woman is a student from Dwarka-New Delhi. She was well built, with a height of $158 \mathrm{cms}$ and weight of 59 kgs. 


\subsubsection{Present Medical History}

Patient on the first day dated 15/11/2020 fell ill and had been selfmedicating in allopathy (drug unknown) for 5 days, but had felt no improvement. After that her father contacted the Siddha Physician at Siddha Clinical Research Unit, Safdarjung hospital, New Delhi for a consultation on 20/11/2020. Presenting symptoms were fever associated with body pain, sore throat, cough, loss of taste (Ageusia) and loss of smell (Anosmia). Since these are the common symptoms of COVID-19, the patient was advised to take RT-PCR (Reverse Transcriptase Polymerase Chain Reaction) for COVID-19 and concurrently the patient was advised to start Siddha medication for her clinical symptoms. She was advised to selfquarantine at home. COVID-19 RT-PCR was positive on dated 21/11/2020. (RT-PCR relies on its ability to amplify a tiny amount of viral genetic material in a sample and is considered to be the gold standard for identification of SARS-CoV-2 virus.)[2]

\subsubsection{Past Medical History:}

She has been a Known case of Bronchial Asthma since 5 years, under low dose inhaled corticosteroids. Patient was not a known case of Diabetes Mellitus / Hypertension/ Thyroid dysfunction/ Primary Tuberculosis or any other co-morbidities.

\section{SIDDHA INTERPRETATION ON THE PATIENT'S CONDITION:}

According to Siddha science, physical body is composed of 5 elements. Mann (Earth), Neer (Water), Thee (Fire), Vaayu (Air), Aagayam (Space). Combination of each elements results in three houmours and the physiological function in the body is mediated by these three humours- Vatham, Pitham, and Kabam. The three humours are said to occupy the lower, middle and upper parts of the body respectively and maintain their integrity. For example, Vatham occupies pelvis and rectum; Pitham occupies stomach and internal viscera and Kabam occupies lungs, throat and head. If these three humours function normally, health is maintained.

In the above mentioned case, the modern diagnosis was arrived by the patient's major symptoms like fever associated with body pain, cough and difficulty to breathe which can be correlated with the Siddha science diagnosis Kaba Suram as per standard Siddha literature. The following Siddha poetry line by Siddha Sage Theraiyar, "Kudarthannil seethamalaathu suramum vaarathu” denotes the pathology of Suram (Fever). Formation of Aamam alias Seetham is the main reason for increasing body temperature (Aamam is the thickening of mucus membrane in the stomach walls). This Aamam is absorbed by the vessels and distributes all over the body and obstructs the excretion of sweat. As per the Siddha poem the lyrics "Kabathinai yandri kaasa swasang -kaanathu" denotes that without the increase of Kabam there is no chance of cough (Kaasam), dysponea (Swaasam).[3]

In the above mentioned case, the diagnosis was initially made, based on the patient's symptoms and the pandemic season. Life style, environmental condition, seasonal variations and food habits causes deranged kabam humour (cough, rhinitis, sore throat) and derangement of Vatham (Uthanan - It is responsible for all the upward movements and Samanan- This is responsible for the neutralization of the other 4 Vali / Vaayu (Air), i.e. Pranan - It is responsible for the respiration, functions of mind, intellect, will power and five sense organs, Abanan - It is responsible for the downward expulsion of stools and urine, ejaculation of semen and menstruation, child birth, Viyanan - It is responsible for the motor and sensory functions of the entire body and the distribution of nutrients to various tissues. and Uthanan. Moreover it is responsible for the nutrients and water balance of the body) causes cough, difficulty in breathing. In the above mentioned case, Kabam and Vatham humor were predominantly deranged. [3] 
A. Aishwarya et.al. A 26-year-old woman with bronchial asthma and COVID -19 treated by stand alone siddha medicine: a case report.

\section{SIDDHA LINE OF TREATMENT}

The medicines supplied to the patient were procured from IMPCOPS (The
Indian Medical Practitioners Co-operative Pharmacy and Stores Ltd) GMP certified manufactures, Chennai, Tamil Nadu.

\section{INTERNAL MEDICINE}

Table 1: Siddha Internal Medicines, Dosage, Adjuvant and Time of Administration

\begin{tabular}{|l|l|c|}
\hline \multicolumn{1}{|c|}{ Medicine } & Dosage and Adjuvant & Time of Administration \\
\hline Kabasura kudineer (Decotion) & $60 \mathrm{ml}$ & Twice a day \\
\hline Brammanandha bairava maathirai (Pill) & 2 pills with Ginger juice & Twice a day \\
\hline Thalisadhi chooranam (Powder) & $2 \mathrm{~g}$ with Honey & Twice a day \\
\hline Amukkara chooranam (Powder) & $2 \mathrm{~g}$ with Milk & Twice a day \\
\hline Adathodai manapagu (Syrup) & $5 \mathrm{ml}$ with Hot water & Twice a day \\
\hline
\end{tabular}

\subsubsection{EXTERNAL MEDICINES AND THERAPIES:}

Table 2: Siddha External Therapies and Mode of Application

\begin{tabular}{|c|c|c|c|c|}
\hline $\begin{array}{l}\text { External } \\
\text { therapies }\end{array}$ & Preparations & $\begin{array}{ll}\text { Mode of } \\
\text { Application }\end{array}$ & Indications & Scientific validation \\
\hline $\begin{array}{l}\text { Ottradam } \\
\text { (Fomentation) }\end{array}$ & $\begin{array}{l}\text { Karpoorathy } \\
\text { Thylam (Oil) }\end{array}$ & $\begin{array}{l}\text { Oil was rubbed } \\
\text { on the chest } \\
\text { region and } \\
\text { fomentation was } \\
\text { given }\end{array}$ & $\begin{array}{l}\text { It relieves Chest congestion, common } \\
\text { cold [4] }\end{array}$ & $\begin{array}{l}\text { Ottradam removes our wastes as } \\
\text { toxins through the skin and balances } \\
\text { Mukkutram (Three humour). It is also } \\
\text { dilating all body channels for the } \\
\text { cleansing. }\end{array}$ \\
\hline $\begin{array}{l}\text { Vedhu } \\
\text { (Steaming) }\end{array}$ & $\begin{array}{l}\text { Karpoorathy } \\
\text { Thylam few drops } \\
\text { and manjal } \\
\text { (Turmeric } \\
\text { powder) poured in } \\
\text { boiled water to } \\
\text { develop vapors. }\end{array}$ & $\begin{array}{l}\text { The body was } \\
\text { covered by a } \\
\text { cotton blanket } \\
\text { and vapor was } \\
\text { inhaled. }\end{array}$ & $\begin{array}{l}\text { Relieves the congestion from the } \\
\text { mucous membrane in bronchitis and } \\
\text { allergic asthma. It expels phlegm from } \\
\text { lower respiratory tract and relaxes } \\
\text { chest muscles, thus reduces cough.[4] }\end{array}$ & $\begin{array}{l}\text { This type of treatment is helpful in } \\
\text { curing Vatham as well as Kabam } \\
\text { diseases.[5] }\end{array}$ \\
\hline $\begin{array}{l}\text { Gargling } \\
\text { /mouth wash }\end{array}$ & $\begin{array}{l}\text { 1.Turmeric [6] } \\
\text { 2.Salt } \\
\text { 3.Thiripala } \\
\text { Chooranam }\end{array}$ & $\begin{array}{l}\begin{array}{l}\text { Patient } \\
\text { advised }\end{array} \\
\text { gargle to } \\
\text { medicines with } \\
\text { luke } \\
\text { water for } 1-2 \\
\text { minutes twice } \\
\text { daily }\end{array}$ & $\begin{array}{l}\text { To reduce intraoral viral load. } \\
\text { “Alaththilurai } \\
\text { nallupppu...kilaiththakaba....pokkung } \\
\text { kaasiniyul maathay kazharu” } \\
\text { Kabam neengum (It will clear } \\
\text { increased Kabam). Salt water gargle } \\
\text { relieves sore and swollen throat.[9] }\end{array}$ & $\begin{array}{l}\text { The effect turmeric observed may be } \\
\text { because of its anti -inflammatory } \\
\text { action.[7] It possesses Anti viral } \\
\text { activities. [8] } \\
\text { Gargling a salt solution, a natural, } \\
\text { and harmless substance, can reduce } \\
\text { the pain and other symptom of sore } \\
\text { throat in patients with non-bacterial } \\
\text { pharyngitis.[10] } \\
\text { Gargling a salt solution, a natural, } \\
\text { and harmless substance, can reduce } \\
\text { the pain and } \\
\text { other symptom of sore throat in } \\
\text { patients } \\
\text { Gargling a salt solution, a natural, } \\
\text { and harmless substance, can reduce } \\
\text { the pain and } \\
\text { other symptom of sore throat in } \\
\text { patients } \\
\text { Triphala is an antiviral operator that } \\
\text { acts against swine flu and other } \\
\text { viruses. [11]. Anti-microbial effect of } \\
\text { Triphala has been proven in-vitro as } \\
\text { it has been shown to } \\
\text { inhibit Streptococcus mutans at } \\
\text { concentrations as low as } \\
50 \mu \text { g/ml.[12] }\end{array}$ \\
\hline
\end{tabular}

\subsubsection{Siddhar Yoga}

Table : 3 Thirumoolar pranayamam

\begin{tabular}{|l|l|l|l|}
\hline Type of Yogam & Frequency & \multicolumn{1}{|c|}{ Method } & Scientific validation \\
\hline $\begin{array}{l}\text { Thirumoolar } \\
\text { Pranayamam } \\
\text { (Yogic } \\
\text { breathing } \\
\text { exercise) }\end{array}$ & $\begin{array}{l}\text { Thrice a } \\
\text { day }\end{array}$ & $\begin{array}{l}\text { It is a practice of ordered breathing. The } \\
\text { process of pranayamam consists of three acts, } \\
\text { namely Pooragam (inspiration) Kumbakam } \\
\text { (retention) and Resagam (expiration). }\end{array}$ & $\begin{array}{l}\text { Recommended for strengthening the respiratory } \\
\text { system to reduce stress. } \\
\text { Several molecules belong to the Immunoglobins super } \\
\text { family, suggesting that pranayamam induces the } \\
\text { molecules to promote immune response as a first line } \\
\text { of defense in the mucosa.[13] }\end{array}$ \\
\hline
\end{tabular}


A. Aishwarya et.al. A 26-year-old woman with bronchial asthma and COVID -19 treated by stand alone siddha medicine: a case report.

\section{STUDY OUTCOME}

The patient tested for COVID-19 RT-PCR positive on 21/11/2020 (Figure 1), but asper the advice of the Siddha consultant from Siddha Clinical Research Unit, Safdarjung Hospital, New Delhi she had already started the Siddha medication for her existing symptoms from $21^{\text {st }}$ November 2020. After intake of combination of Siddha medicines as standalone treatment the patient's temperature decreased within 2 days. The patient reported resolution of most of her symptoms after 9 days and the patient's RTPCR test was negative on 10/12/2020 (Figure 1).

Table 4: Day by day improvement of patient's health condition
\begin{tabular}{|l|l|}
\hline Date & Patient Condition \\
\hline $15 / 11 / 2020$ & Temperature-101 ${ }^{\circ}$ F, Sore throat \\
\hline $20 / 11 / 2020$ & $\begin{array}{l}\text { Loss of smell and taste. Temperature became } \\
\text { normal. } \\
\text { COVID-19 RT-PCR positive }\end{array}$ \\
\hline $26 / 11 / 2020$ & Cough, Body pain \\
\hline $04 / 12 / 2020$ & $\begin{array}{l}\text { Smell and taste returned normal. Other symptoms } \\
\text { reduced. }\end{array}$ \\
\hline $10 / 12 / 2020$ & $\begin{array}{l}\text { COVID-19 RT-PCR Negative. Mild body pain } \\
\text { persist. }\end{array}$ \\
\hline
\end{tabular}

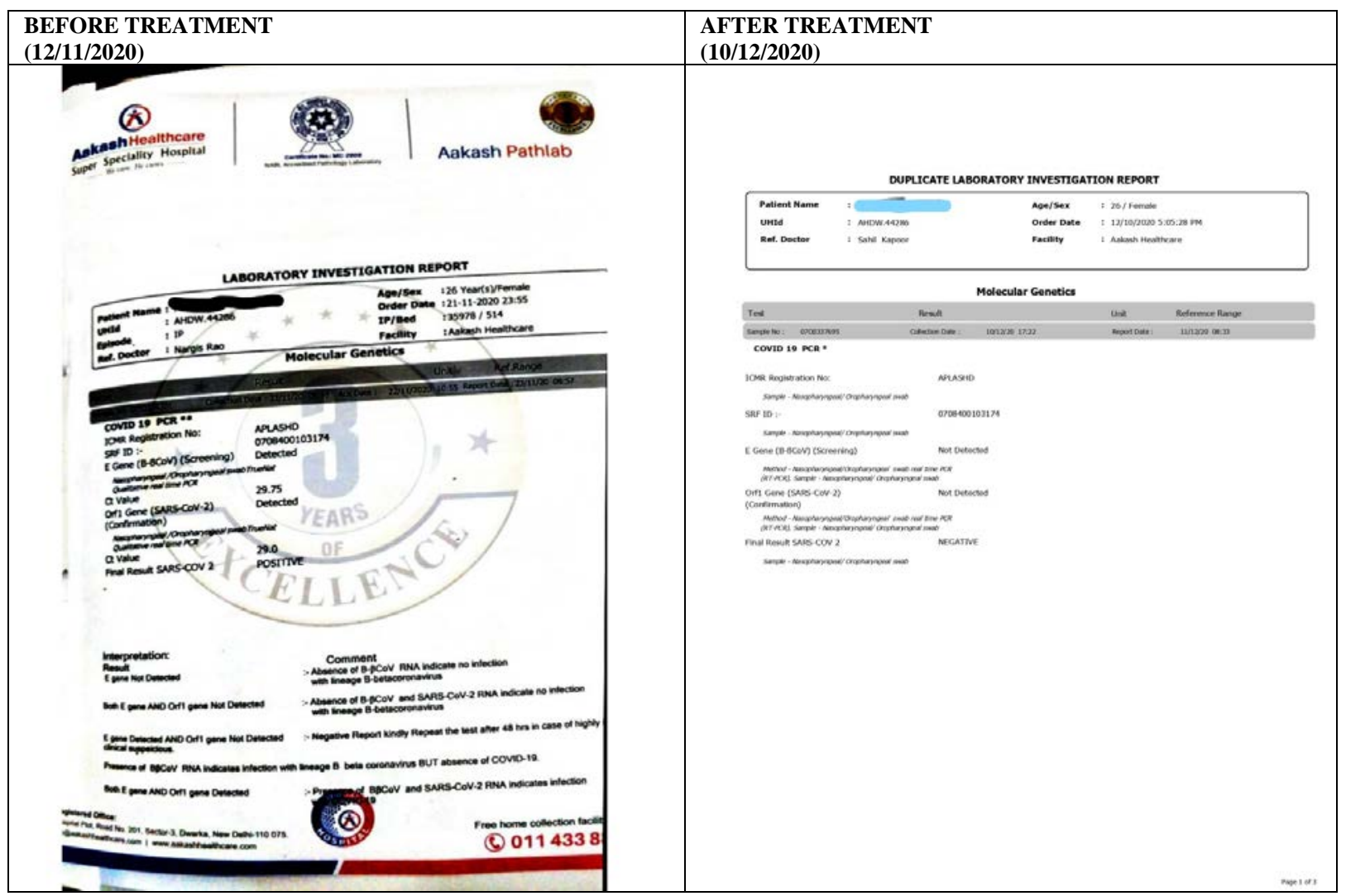

FIGURE 1: COVID-19 DETECTED BY RT-PCR

There was resolution of symptoms gradually, and there was no progression of the disease to a severe stage. There were no adverse or unanticipated events.

\section{DISCUSSION}

The symptoms of COVID-19 can be correlated with Kabasuram, which is a Kabam predominance.[1] The medicines used for managing the condition had to be selected from a set of medicines which was mentioned for Kabam related diseases in
Siddha literatures. There are a large number of Siddha medicines that are currently in use for all types of Kabam related diseases which may prove to be effective for COVID-19.

Presently with COVID-19 patient was already known case of Bronchial Asthma for 5 years. The existence of underlying conditions, especially chronic respiratory diseases, may affect the progress, treatment and prognosis of COVID-19.[14] 


\section{DELHI WEATHER BY MONTH // WEATHER AVERAGES}

\begin{tabular}{|c|c|c|c|c|c|c|c|c|c|c|c|c|}
\hline & January & February & March & April & May & June & July & August & September & October & November & December \\
\hline Avg. Temperature $\left({ }^{\circ} \mathrm{C}\right)$ & 14.2 & 16.9 & 22.6 & 28.4 & 33.3 & 34.1 & 31 & 29.7 & 29.1 & 25.7 & 20 & 15.7 \\
\hline Min. Temperature $\left({ }^{\circ} \mathrm{C}\right)$ & 7.3 & 10 & 15 & 20.7 & 26.2 & 28.4 & 27 & 25.9 & 24.4 & 18.5 & 11.6 & 8 \\
\hline Max. Temperature ( $\left({ }^{\circ} \mathrm{C}\right)$ & 21.1 & 23.8 & 30.2 & 36.2 & 40.4 & 39.8 & 35.1 & 33.5 & 33.9 & 32.9 & 28.5 & 23.4 \\
\hline $\begin{array}{l}\text { Precipitation / Rainfall } \\
(\mathrm{mm})\end{array}$ & 15 & 11 & 15 & 3 & 12 & 44 & 217 & 271 & 114 & 27 & 4 & \\
\hline
\end{tabular}

FIGURE 2-Delhi weather in December 2020 [16]

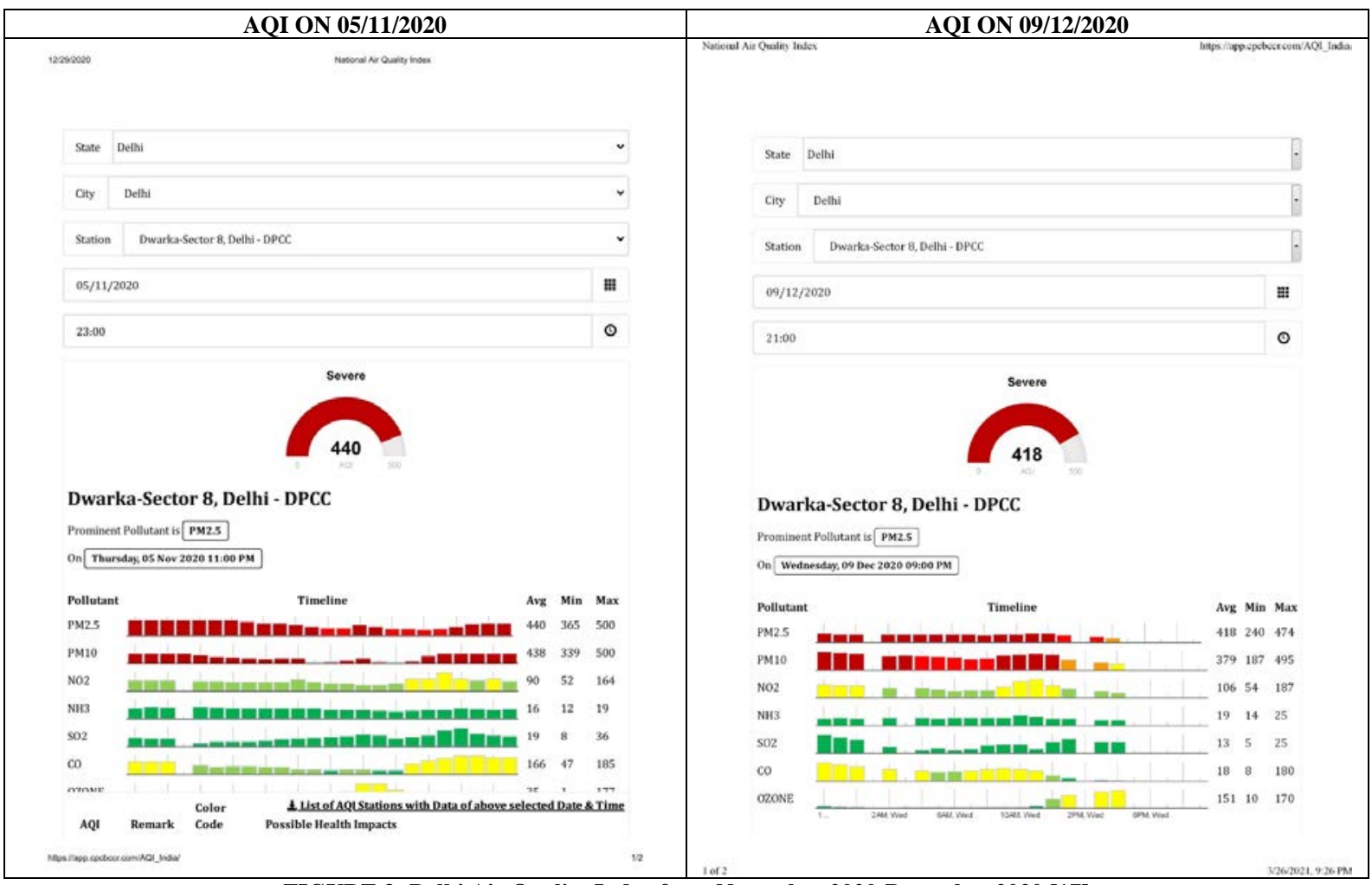

FIGURE 3- Delhi Air Quality Index from November 2020-December 2020 [17]

Since the patient had bronchial asthma as a co-morbid condition, both the winter season (Figure 2) and air pollution (Figure 3) are likely to increase the severity of the disease. Central pollution control board, Ministry of environment reported the air quality index in the area Dwarka where the patient resided has been very poor (AQI 300-400 approx.) during the months of November and December 2020.(Figure 3).

Exposure to air pollution especially $\mathrm{NO}_{2}$ (Nitrogen Dioxide) and $\mathrm{PM}_{2.5}$ (Particulate matter the mass per cubic metre of air of particles with a size generally less than 2.5 micrometers) may increase the susceptibility of infection and mortality from COVID-19. Air pollution can cause adverse effects on the prognosis of patients affected by SARS-CoV-2 infection. Air quality should be counted as an important part of an integrated approach toward public health protection and prevention to the spread of epidemics.[15]

Even though the above ancillary factors that increase the severity of COVID19 , the patient had responded well to the Siddha management. The patient was under follow up to assess the occurrence of post COVID complications for three months to till date. (23/03/2021). 


\section{CONCLUSION}

SARS CoV-2 that mainly affects the respiratory system. In this particular case the patient has already affected by bronchial asthma as a respiratory co-morbid condition, both air pollution and winter are likely to increase the severity of the disease. Therefore, this case study reveals that Siddha treatment is more effective in the treatment of COVID-19 along with bronchial asthma as a co-morbid condition and also it prevents the deterioration of disease into a more critical condition. This is also a valuable opportunity for demonstrating the efficacy of Siddha intervention in this pandemic situation.

\section{Acknowledgement: None}

\section{Conflict of Interest: None}

\section{Source of Funding: None}

\section{REFERENCES}

1. A.Aishwarya, B.K.Priya.,et.al, Iyya Irumal (Identical to COVID -19) ---Its Pathological Aspects and Management Theories in Siddha, IOSR Journal of Dental and Medical Sciences (IOSRJDMS), Volume 19, Issue 6 Ser.6 (June. 2020), PP 17-30

2. Linda J. Carter et.al., Assay Techniques and Test Development for COVID-19 Diagnosis, ACS Cent Sci. 2020 May 27; 6(5): 591-605. Published online 2020 Apr 30. doi: 10.1021/acscentsci.0c00501,

3. Shanmughavelu, H.P.I.M., Noinaadal Noimudhal Naadal Thirattu Part 1, First Edition, Published by D I M\& H , Chennai, Pg no-17,72-75,79, 364.

4. G.Senthilvel ,J.Jeyavenkatesh et..al., A complete manual on Siddha external therapies, Shanlax publication-2017, Madurai, Pg no-35, 46, 70, 77, 103.

5. Uthamarayan $\mathrm{K}$ S. Siddhar Aruvai Maruthuvam, Chennai: Department of Indian medicine and Homeopathy, 4th edition, 2005, Pg no - 44, 45.

6. K.S.Murugesa mudhaliyar, Gunapadam Mooligai Vaguppu 7th edition 2003, ,
Department of Indian medicine and Homoeopathy. Chennai-10 pg no-721

7. Nagpal M, Sood S. Role of Curcumin in systemic and oral health: An overview. J Nat SciBiol Med. 2013;4(1):3-7. doi:10.4103/0976-9668.107253

8. Moghadamtousi, Soheil Zorofchian et al. "A review on antibacterial, antiviral, and antifungal activity of curcumin.” BioMed research international vol. 2014 (2014): 186864. doi:10.1155/2014/186864

9. Dr.R.Thyagarajan LIM; Gunapadam Thathujeevam vagupu- 2016 (9th edition): Indian Medicine and Homeopathy Pg:385,392

10. Mohmad Sallih, Mohd Azreen Ezairy \& Zulkiflee, AB. (2019). Randomised Controlled Trial of Salt Solution (Sodium Chloride) Mouth Wash vs Thymol Glycerine Usage in Sore Throat with Non Bacterial Pharyngitis. Journal of Complementary and Alternative Medical Research. 1-5. 10.9734/jocamr/2019/v7i430110.

11. Tarasiuk, Aleksandra et al. "Triphala: current applications and new perspectives on the treatment of functional gastrointestinal disorders." Chinese medicine vol. 13 39. 18 Jul. 2018, doi:10.1186/s13020-018-0197-6

12. Prakash S, Shelke AU. Role of Triphala in dentistry. J Indian SocPeriodontol. 2014;18(2):132-135. doi:10.4103/0972124X.131299

13. Sundaravadivel Balasubramanian et.al., Alterations in Salivary Proteome following Single Twenty-Minute Session of Yogic Breathing/ Complementary and Alternative Medicine in Cancer Prevention and Therapy/ Volume 2015 |Article ID 376029 | 10 pages | https://doi.org/10.1155/2015/376029

14. Wang $\mathrm{D}, \mathrm{Hu} \mathrm{B}, \mathrm{Hu} \mathrm{C}$, Zhu F, Liu X, Zhang J, Wang $B$, Xiang $\mathrm{H}$, Cheng $\mathrm{Z}$, Xiong Y, Zhao Y, Li Y, Wang X, Peng Z. Clinical Characteristics of 138 Hospitalized Patients With 2019 Novel Coronavirus-Infected Pneumonia in Wuhan, China. JAMA. 2020;323:10611069

15. Nurshad Ali, Farjana Islam, The Effects of Air Pollution on COVID-19 Infection and 
A. Aishwarya et.al. A 26-year-old woman with bronchial asthma and COVID -19 treated by stand alone siddha medicine: a case report.

Mortality- A Review on Recent Evidence, Front. Public Health, 26 November 2020 https://doi.org/10.3389/fpubh.2020.58005 7

16. Available from: https://en.climatedata.org/asia/india/delhi/new-delhi30/t/december-12/

17. Available https://app.cpcbccr.com/AQI_India/ from:
How to cite this article: A. Aishwarya, B. K. Priya, B. Akila et.al. A 26-year-old woman with bronchial asthma and COVID -19 treated by stand alone siddha medicine: a case report. Int J Health Sci Res. 2021; 11(11): 313-319. DOI: https://doi.org/10.52403/ijhsr.20211137 